\title{
A BACTERIOLOGICAL INVESTIGATION OF ARTIFICIAL MINERAL WATERS.
}

\author{
By Charles Slater, M.A., M.B. (Cantab), Lecturer on Bacteriology, \\ St. George's Hospital, London.
}

THE practical aim of the following investigation was to determine how far the use of artificial aërated waters was a safeguard against the transmission of water-carried diseases. Under long continued hygienic teaching, the public has become fully alive to the dangers of contaminated water, and there is no doubt that a very large proportion of the mineral water drunk is consumed because, in addition to its pleasantness, or the supposed therapeutic value of the contained alkaline salts, it is thought to offer practical immunity from the danger of specific infection. That this is the case, and that manufacturers recognise it, is obvious from the advertisements-of the various makers in which they insist either on the purity of the source of supply, or on the precautions taken during manufacture to secure the biological purity of the aërated water.

The danger arising from metallic contamination, especially lead, owing to the increased solvent action of water saturated with carbon dioxide on the pipes, pressure cylinders, syphon heads, etc., has been recognised for some years. This source of danger has now, however, been practically eliminated in the better class of mineral waters by the use of block tin pipes, thickly tinned cylinders, and syphon heads consisting of almost pure tin, or protected by porcelain linings or electro-plating.

The dangers arising from the possibility of contamination with the micro-organisms of specific diseases have more recently attracted attention, and it is to the diminution of risks from this source that the manufacturers have lately directed their efforts. It is with this side of the question, the biological purity of the water, that this inquiry is concerned, and it was undertaken to discover how far the opinion as to the greater safety of aërated waters was justified, and how far the methods of manufacture intended to increase the organic purity of the waters were efficient. 
The points investigated were-

1. The source of the water and the methods employed in its purification.

2. The number and nature of the micro-organisms present in mineral waters derived from various sources.

3. The action of $\mathrm{CO}_{2}$ on the microbes present in artificial waters.

4. The action of $\mathrm{CO}_{2}$ under varying pressures on certain pathogenic organisms.

The mineral waters examined were either simple aërated or alkaline waters, obtained, by the courtesy of various leading London makers, direct from the factories, and were selected to show what was the influence of variation in source of supply, or subsequent treatment on the bacteriology of the finished waters.

\section{The Sources and Methods of Purification.}

It was found that the waters employed in London might be grouped into four chief varieties, according to the original sources of the water or the methods of purification employed before aëration. These groups are-

$A$. River or deep-well water as supplied by one of the London water companies. The water was used direct from the mains or after charcoal filtration and subjection to a softening process.

$B$. Artesian-well water from private wells situated in different parts of the London district. This water was generally filtered through either animal or block charcoal.

C. Distilled water. This was water derived from one of the water companies, distilled under pressure, the pressure varying from 20 to 35 lbs. per square inch. Occasionally the water was distilled at $100^{\circ} \mathrm{C}$. The distilled water after condensation, which was effected in tin-lined condensers, was filtered through either animal or wood charcoal, in order to remove the peculiar mawkish flavour of distilled water. The charcoal apparently acts by oxidation of a volatile organic compound which, as well as the want of aëration, is the cause of the distinctive taste.

$D$. Boiled water. The water supplied by a water company after filtration through spongy iron filters was treated with sodium carbonate (a softening process) and potassium permanganate, and then boiled by steam coils, in covered tanks. The openings to the tanks were protected by cotton-wool plugs in inverted U-tubes. The water was then syphoned off and filtered through pounded glass into another covered and protected tank, from which it passed to the aërating machines.

The waters employed, then, are very varied, and include river, deepwell, artesian-well, distilled and boiled water; and as these varieties are known to be biologically very different, it might be expected that the 
finished aërated waters prepared from these varied sources would present strongly marked differences.

\section{Bacteriological Examination of Artificial Ä̈rated Waters.}

The waters examined were simple aërated, soda, potash, or lithia waters. They were contained in syphons or corked bottles. The examination in the case of the syphons was conducted as follows: The syphon nozzle was rinsed by discharging some of the water, then

TABLE A.

Examination of Aërated Waters within 24 Hours of Aëration.

\begin{tabular}{|c|c|c|c|c|c|c|c|c|c|}
\hline \multirow[b]{2}{*}{ Source of Water. } & \multirow{2}{*}{ 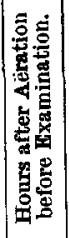 } & \multirow{2}{*}{ 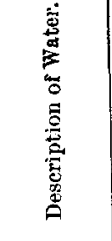 } & \multirow{2}{*}{ 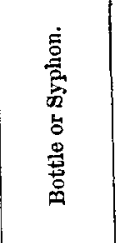 } & \multirow{2}{*}{ 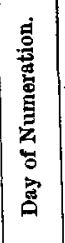 } & \multicolumn{3}{|c|}{ Organisns per c.c. } & \multicolumn{2}{|c|}{$\begin{array}{l}\text { Ammonia per } \\
100,000 \text { pts. }\end{array}$} \\
\hline & & & & & 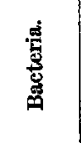 & 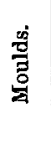 & 离 & Free. & 突 \\
\hline $\begin{array}{l}\text { 1. Water, Class B ; }{ }^{1} \\
\text { block carbon } \\
\text { filter. } \\
\text { 2. } \\
\text { 3. Do. } \\
\text { Do. }\end{array}$ & $\begin{array}{r}5 \\
3 \frac{1}{2} \\
4 \frac{1}{2}\end{array}$ & $\begin{array}{c}\text { Simple } \\
\text { aërated. } \\
\text { Do. } \\
\text { Do. }\end{array}$ & \begin{tabular}{|} 
Syphon. \\
Do. \\
Do.
\end{tabular} & $\begin{array}{l}\text { 3rd. } \\
\text { 3rd. } \\
6 \text { th. }\end{array}$ & \begin{tabular}{r|}
477 \\
\\
431 \\
2874
\end{tabular} & $\begin{array}{r}2 \\
45\end{array}$ & $\begin{array}{r}480 \\
\\
433 \\
2919\end{array}$ & $\ddot{006}$ & 01383 \\
\hline $\begin{array}{l}\text { 4. Water, Class B ; } \\
\text { animal charcual } \\
\text { filtration. } \\
\text { 5. Do. }\end{array}$ & $\begin{array}{l}18 \\
18\end{array}$ & $\begin{array}{c}\text { Soda- } \\
\text { water. } \\
\text { Do. }\end{array}$ & $\begin{array}{c}\text { Syphon. } \\
\text { Do. }\end{array}$ & $\begin{array}{l}8 \text { th. } \\
3 \text { rd. }\end{array}$ & $\begin{array}{r}1048 \\
594\end{array}$ & $\begin{array}{l}\cdots \\
51\end{array}$ & $\begin{array}{r}1048 \\
645\end{array}$ & Trace. & .00184 \\
\hline $\begin{array}{l}\text { 6. Water, Class D. } \\
\text { 7. } \quad \text { Do. }\end{array}$ & $\begin{array}{c}5 \\
18 \\
\text { (ice) }\end{array}$ & \begin{tabular}{|} 
Simple \\
aërated. \\
Do.
\end{tabular} & $\begin{array}{c}\text { Syphon. } \\
\text { Corked } \\
\text { bottle. }\end{array}$ & $\begin{array}{l}5 \text { th. } \\
8 \text { th. }\end{array}$ & $\begin{array}{r}649 \\
1170\end{array}$ & $\ldots$ & $\begin{array}{r}649 \\
1214\end{array}$ & $\begin{array}{c}\cdots \\
\ldots\end{array}$ & $\begin{array}{c}\cdots \\
\ldots\end{array}$ \\
\hline 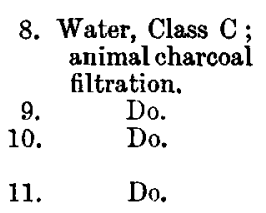 & $\begin{array}{l}18 \\
\text { Do. } \\
\text { Do. } \\
\text { Do. }\end{array}$ & \begin{tabular}{|c|} 
Simple \\
aërated. \\
Do. \\
Soda- \\
water. \\
Do.
\end{tabular} & \begin{tabular}{|c|}
$\begin{array}{c}\text { Corked } \\
\text { bottle. }\end{array}$ \\
Do. \\
Do. \\
Do.
\end{tabular} & $\begin{array}{l}6 \text { th } \\
4 \text { th } \\
4 \text { th }\end{array}$ & $\begin{array}{r}1007 \\
\\
350 \\
1066 \\
353\end{array}$ & $\begin{array}{r}4 \\
469 \\
226\end{array}$ & $\begin{array}{r}1089 \\
\\
354 \\
1535 \\
579\end{array}$ & $\begin{array}{l}\cdots \\
\cdots\end{array}$ & $\begin{array}{l}\cdots \\
\cdots \\
\cdots\end{array}$ \\
\hline
\end{tabular}

1 The classes given are those into which the varieties of water used are grouped in the text.

swabbed out with alcohol, then rinsed once more with the water, the outside heated by passing through the flame, and a portion of the water then drawn into a sterile plugged test tube. From this tube the water was withdrawn in a sterile bulb pipette.

In the case of the corked bottles, after carefully washing the neck with mercury perchloride, and subsequently with alcohol, the cork was loosened, the gas allowed in great part to escape, and then the cork rapidly removed and replaced by a sterile wool plug. Through this 
plug the water was withdrawn into sterile bulb pipettes. With water so withdrawn nutrient gelatine was inoculated in the usual way, and spread out in Petri's capsules. In nearly all cases the amount of water employed was estimated by weighing, but in a few cases graduated pipettes were used, the latter only where the amount taken was comparatively large.

The use of pipettes to measure the water was found not to be sufficiently accurate where small quantities of water were employed, owing to the formation of gas bubbles in the pipette. Even when the waters had

\section{TABLe B.}

Examination of Aërated Waters kept 48 Hours to 7 Days after Aëration.

\begin{tabular}{|c|c|c|c|c|c|c|c|c|c|}
\hline \multirow[b]{2}{*}{ Source of Water. } & \multirow{2}{*}{ 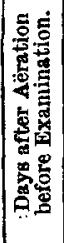 } & \multirow{2}{*}{ 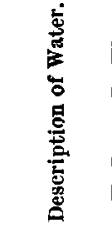 } & \multirow{2}{*}{ 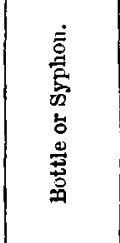 } & \multirow{2}{*}{ 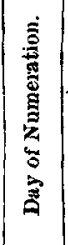 } & \multicolumn{3}{|c|}{ Organjsms per c.c. } & \multicolumn{2}{|c|}{$\begin{array}{l}\text { Ammonia per } \\
100,000 \text { pts. }\end{array}$} \\
\hline & & & & & 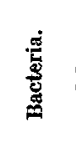 & $\frac{8}{\tilde{z}}$ & 孪 & Free. & 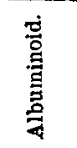 \\
\hline $\begin{array}{l}\text { 12. Water, Class C; } \\
\text { wood charcoal } \\
\text { filtration. } \\
\text { 13. Do. }\end{array}$ & 2 & $\begin{array}{l}\text { Non- } \\
\text { aërated. }\end{array}$ & $\begin{array}{c}\text { Corked } \\
\text { bottle. }\end{array}$ & 2nd. & 77 & $\ldots$ & 777 & .0276 & .004 \\
\hline I4. Do. & 5 & $\begin{array}{l}\text { water. } \\
\text { Simple } \\
\text { aërated. }\end{array}$ & Do. & ith. & 750 & 2 & 752 & .004 & .004 \\
\hline $\begin{array}{l}\text { 15. Water, Class A ; } \\
\text { unfiltered, soft- } \\
\text { ened. }\end{array}$ & 4 & $\begin{array}{c}\text { Soda- } \\
\text { water. }\end{array}$ & $\begin{array}{c}\text { Corked } \\
\text { bottles. }\end{array}$ & 2nd. & 2615 & $\ldots$ & 2615 & $\cdot 0032$ & .0138 \\
\hline 16. Do. & $\mathbf{5}$ & $\begin{array}{l}\text { Lithia. } \\
\text { water. }\end{array}$ & Do. & 3rd. & 410 & $\ldots$ & 410 & $\cdots$ & $\cdots$ \\
\hline $\begin{array}{l}\text { 17. Water, Class C ; } \\
\text { animal charcoal } \\
\text { fltration. }\end{array}$ & 6 & $\begin{array}{l}\text { Simple } \\
\text { aërated. }\end{array}$ & Do. & 8th. & 38 & 13 & 51 & .0044 & .003 \\
\hline 18. Do. & 6 & $\begin{array}{c}\text { Soda- } \\
\text { water. }\end{array}$ & Do. & 8th. & 218 & 310 & 558 & $\cdots$ & $\cdots$ \\
\hline 19. & 6 & $\begin{array}{l}\text { Potash- } \\
\text { water. }\end{array}$ & Do. & 8th. & 215 & 18 & 233 & .001 & $\cdot 004$ \\
\hline 20. Origin unknown. & $?$ & $\begin{array}{l}\text { Soda- } \\
\text { water. }\end{array}$ & $\begin{array}{l}\text { Bottle, } \\
\text { ball } \\
\text { cork. }\end{array}$ & 2nd. & 2006 & $\cdots$ & 2006 & $\cdot 006$ & .001 \\
\hline
\end{tabular}

been uncorked for some time, and all evolution of gas had apparently ceased, suction of the water into the pipettes was followed by the development of bubbles in greater or less number. The bottles or syphons were not specially shaken to diffuse the organisms, as ordinary handling, together with the extremely vigorous agitation following the escape of the gas, was quite enough to effect this object. The same 
remarks apply to the syphons, the washing out of the nozzle and tubes leading to general agitation by escaping $\mathrm{CO}_{2}$.

The results of the examination are arranged in Tables $A, B$, and $C$. Table A shows the results of analysis-bacteriological and, in some cases, chemical-of aërated waters made within 24 hours of manufacture. Table B shows similar results from analyses undertaken between 2 and 7 days after aëration, and Table $\mathrm{C}$ of the analysis of waters more than 3 weeks old.

TABLE C.

Examination of Aërated Waters 3 Weeks or more after Aëration.

\begin{tabular}{|c|c|c|c|c|c|c|c|c|c|}
\hline \multirow{2}{*}{ Source of Water. } & \multirow{2}{*}{ 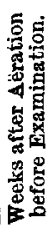 } & \multirow{2}{*}{ 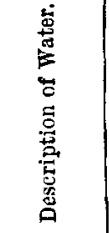 } & \multirow{2}{*}{ 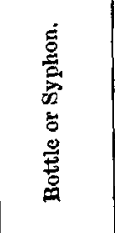 } & \multirow{2}{*}{ 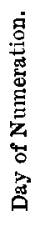 } & \multicolumn{3}{|c|}{ Organisms per c,c. } & \multicolumn{2}{|c|}{$\begin{array}{l}\text { Amounts per } \\
100,000 \text { pts. }\end{array}$} \\
\hline & & & & & 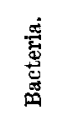 & $\frac{3}{3}$ & 蹗 & Free. & 莺 \\
\hline $\begin{array}{l}\text { 21. Water, Class A. } \\
\text { eharcoal filtra- } \\
\text { tion, softening. }\end{array}$ & 3 & $\begin{array}{c}\text { Soda- } \\
\text { water. }\end{array}$ & $\begin{array}{c}\text { Corked } \\
\text { bottle. }\end{array}$ & 9 & 25 & 9 & 34 & $\cdot 00184$ & .0092 \\
\hline 22. Water, Class D; & 3 & Simple & Syphon. & 8 & 2 & 1 & 3 & $\cdot 001$ & .001 \\
\hline 23. & 4 & Potash. & Do. & 8 & 4 & 38 & 42 & Trace. & Trace. \\
\hline & 4 & Soda- & Do. & 8 & 265 & 3 & 268 & $\cdot 004$ & $\cdot 004$ \\
\hline $\begin{array}{l}\text { 25. Distilled water, } \\
\text { no filtration. }\end{array}$ & 4 & $\begin{array}{l}\text { Lithia- } \\
\text { water. }\end{array}$ & & 8 & 2 & 1 & 3 & $\cdot 003$ & Trace. \\
\hline 26. Water, Class D. & 4 & $\begin{array}{l}\text { Simple } \\
\text { aërated. }\end{array}$ & $\begin{array}{c}\text { Corked } \\
\text { bottle. }\end{array}$ & 7 & $0(?)$ & 36 & 36 & .006 & .002 \\
\hline $\begin{array}{l}\text { 27. Distilled un- } \\
\text { filtered. }\end{array}$ & 4 & Lithia. & Do. & 10 & 16 & 8 & 24 & & \\
\hline $\begin{array}{l}\text { 28. Water, Class A ; } \\
\text { unfiltered, soft- } \\
\text { ened. }\end{array}$ & 6 & $\begin{array}{l}\text { Lithia- } \\
\text { water. }\end{array}$ & $\begin{array}{c}\text { Corked } \\
\text { bottle. }\end{array}$ & 10 & 33 & 1 & 34 & $\ldots$ & $\cdots$ \\
\hline 29. Water, Class D. & 10 & $\begin{array}{l}\text { Simple } \\
\text { aërated. }\end{array}$ & $\begin{array}{c}\text { Corked } \\
\text { bottle. }\end{array}$ & 10 & 49 & 3 & 52 & $\cdots$ & $\ldots$ \\
\hline $\begin{array}{l}\text { 30. Water, Class A ; } \\
\text { animal charcoal } \\
\text { filtration. }\end{array}$ & 20 & Lithia. & $\begin{array}{c}\text { Corked } \\
\text { bottle. }\end{array}$ & 10 & 2000 & 0 & 2000 & $\ldots$ & $\ldots$ \\
\hline
\end{tabular}

The number of micro-organisms present in the different samples is in most cases considerable, but varies between somewhat wide limits. The largest number observed was 2919, the smallest 354 (24 hours old) to 3 (in water 3 weeks old). In no case did my results, even where the enumeration could be postponed to the sixth or eighth day, show the presence of so large a numer of organisms as was found by Hochstetter 
in German mineral waters; the number in 8 bottles examined by this observer varying from 10,000 to 75,000 .

A comparison of the results of analysis of simple aërated waters and those containing alkaline salts, especially sodium carbonate, would seem to show, where comparison is possible, that the latter contain the greater number of organisms. Sohnke has shown that solutions of sodium chloride and sodium bicarbonate, made in sterile vessels with sterile water and unfiltered, contain considerable numbers of moulds and bacteria. Numbers which indicate this increased richness of the alkaline waters are-

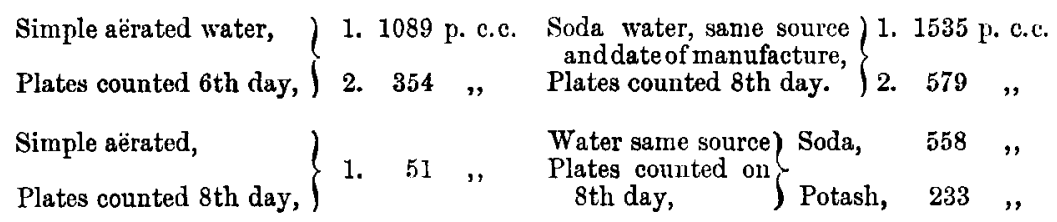

Variations of individual samples are, however, so great that it is difficult to draw any decided conclusion on this point.

The colonies which developed were for the most part composed of bacilli. Micrococci were present in much smaller numbers, and yeasts (torula alba and rosea) occurred very rarely, and generally in aërated waters, made by manufacturers who were also bottlers of beer, etc. The moulds varied greatly in numbers, and seemed on the whole to be more numerous in corked bottles than in syphons. The most common mould was $P$. glaucum, but aspergilli and mucors also occurred.

The number of varieties of bacteria present was rarely large, and in most cases was restricted to three or four, even in those waters containing a large total number.

The constant and most conspicuous were-(1) a rapidly growing bacillus which liquefies the gelatine and produces a brilliant green fluorescence-probably B. fuorescens liquefaciens (Flügge), and a slowly developing, non-liquefactive bacillus producing a yellow pigmentB. luteus (Flügge). There appeared to be several varieties of the fluorescing organism, indistinguishable under the microscope, but showing differences in rate of liquefaction, amount of pigment produced, and form of colonies. There was also in certain waters a non-liquefactive brilliantly fluorescing bacillus, possibly $B$. fuorescens putidus (Flügge). The $B$. fuorescens liquefaciens was met with in every water, and when present in any considerable number prevented the counting of the colonies after the second or third day. In looking at the total organisms per c.c. given in the Table, it is therefore necessary to look also at the date of numeration, as the maximum appearance of colonies occurred on the third or fourth days, so that while some of the totals represent the actual numbers of organisms present, with the usual reservations necessary in regard to all bacteriological analyses, others merely represent a minimum. The actual proportion of liquefying to non-liquefactive 
organisms present, even in those waters containing a considerable number, was never large.

Occasionally a water was found in which the cocci bore a much larger proportion to the bacilli than was usual. This was the case with water No. 4, Table A, in which $M$. aurantiacus (Schröter) occurred in considerable numbers.

Other organisms met with were B. flavus liquefaciens (Macé), Sarcina flava, B. subtilis, and a large non-liquefactive motile bacillus.

It would appear, then, that the differences in the source of the water supply, or the purifying treatment it undergoes, can scarcely be traced in the finished waters. Hochstetter found in his examination of Berlin mineral waters that individual samples made from the same bulk of water vary greatly. Reinl, too, noticed the great variation in individual samples of bottled natural mineral waters. My results show the same thing. It is certain that the greater or less biological purity of the original supply is masked by contaminations which occur during manufacture. These secondary sources of contamination comprise-(1) the storage tanks, (2) the filters employed, (3) the bottles, and (4) the corks. The latter two sources of contamination should be the chief cause of the variation of individual samples. The certainty of originally sterile water becoming once more full of organisms in its passage through storage tanks, filters, etc., or by bottling in non-sterile bottles, is so obvious that discussion of the nutter would be useless were it not important to discover whether at any of these points pathogenic germs, as distinguished from ordinary saprophytes, might gain entrance. As shown above, the bacteriological examination gives no information as to the original purity of the source of supply. It is useless and would be foolish to demand that makers should send out sterile water, if it can be shown that the precautions taken effectually prevent the access of pathogenic germs. In discussing, then, the sources of contamination, attention is here directed solely to the possible entry of disease-producing organisms. First, with regard to the original supply. The waters of Group A are the ordinary drinking waters supplied to the metropolis. Opinions differ as to the absolute freedom of these waters from at least the risk of contamination with disease germs. It must be remembered that in most of the eases of typhoid, which are attributed to the nse of impure drinking water, the water impurities can be shown to have gained access owing to local conditions of improper storage, communication with drains, etc., and not to have existed in the water as supplied from the mains. The second group, the artesian-well waters, are admittedly very pure and safe waters, always provided contamination with surface water is efficiently prevented. In London the water of artesian-wells rises only part way to the surface, and has to be raised by pumping. 'This often means that the upper part of the well is not the simple impermeable iron pipe which constitutes the lower part. The waters of Groups $\mathrm{C}$ and $\mathrm{D}$ are practically microbe free as they leave the stills or 
boiling tanks, and certainly could not contain the germs of any of the ordinary water-borne diseases. The water, however, is not used as it comes direct from the stills, but is first filtered through animal or vegetable charcoal to remove the peculiar distilled water taste. Here the biological purity is at once destroyed, but as the charcoal appears to be very carefully selected, freshly burnt, frequently changed, and very thoroughly washed, in situ, with the purified water before use, the risk of dangerous contamination must be infinitesimal. The boiled water was filtered through glass to remove the deposited lime, etc. These filters were cleansed by washing with sulphurous acid, potassium permanganate, and final washing with boiled water.

For the storage of the waters slate tanks are usually employed, and these, in the factories visited, were well situated, carefully protected, frequently emptied in the ordinary course of manufacture, and kept scrupulously clean. In considering the last sources of contamination, the bottles and corks, distinction must be made between syphons and corked bottles. Syphons are cleansed by partially filling with aërated water, rinsing them with this, and then discharging the water so used. They are, therefore, washed with the same quality of water which is afterwards used for drinking, and no fresh source of contamination is introduced. The bottles are cleansed by soaking in hot water, brushing out with hand or revolving brushes, and finally inverting over a jet of water at high pressure which thoroughly rinses them. The bottles are subsequently carefully inspected before use. The thoroughness with which the cleansing is done and the amount of inspection varies considerably in different factories, and during the summer months, when there is a difficulty in keeping up with the demand, the washing is made as short as possible and perhaps occasionally omitted.

The spray with which the final rinsing is done is usually obtained from the mains of the company in whose district the factory lies, this supply being the most convenient on account of the available pressure. As a result, the water which has been boiled, distilled, or otherwise purified, is finally bottled with an admixture of ordinary tap water, thus reintroducing, though in a diluted form, the dangers surrounding the use of untreated water. The use of main water for rinsing, by the manufacturer whose aërated water is made from the same supply, is logical enough, but those makers who work on the assumption that purification processes are necessary to secure the safety of the waters should avoid thus stultifying their efforts. An examination of bottles has shown, as was to be expected, that they are far from sterile. They are used almost directly as they come from the spray, that is while still very wet, or after standing inverted for a day or two to drain. It was found by experiment, however, that in the great majority of inverted bottles, 48 hours after rinsing, there was a considerable quantity of unevaporated water, which gave rise to copious growths in mutrient bouillon.

Corks must also add to the number of organisms present in the 
bottled waters, though the risk of the entrance of pathogenic germs by this route is probably very small. Some makers, however, pay attention to this matter, and wash the corks in alkaline solutions, in solutions of sulphurous acid, and finally in water. Others enclose the corks in wire cages and immerse them in boiling water, while others merely dust them by rolling, and soften them with hot water.

In a few instances it has been possible to examine the water on its way to the aërating cylinders, and the same water after aëration and softening, i.e. the water before and after the final source of contamination in the bottles and syphons.

TABLe D.

Examination of Water before and after Aëration.

\begin{tabular}{|c|c|c|c|c|c|c|}
\hline \multirow{2}{*}{ Origin of Water. } & \multirow{2}{*}{$\begin{array}{c}\text { Time of } \\
\text { Examination. }\end{array}$} & \multirow{2}{*}{ 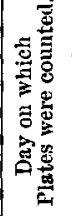 } & \multicolumn{3}{|c|}{$\begin{array}{c}\text { Number of Organisms } \\
\text { per c.c. }\end{array}$} & \\
\hline & & & 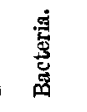 & 总 & 总 & \\
\hline $\begin{array}{l}\text { 1. Water of Class B; filtered } \\
\text { through block charcoal, drawn } \\
\text { in sterile bulb pipette. } \\
\text { 2. The same water after aëration, } \\
\text { in syphon. }\end{array}$ & $\begin{array}{l}3 \text { hours after } \\
\text { drawing. } \\
3 \text { hours after } \\
\text { aëration. }\end{array}$ & $\begin{array}{l}\text { 4th. } \\
\text { 3rd. }\end{array}$ & $\begin{array}{r}2162 \\
431\end{array}$ & 10 & 2172 & $\begin{array}{l}\text { Before } \\
\text { aëration. } \\
\text { After } \\
\text { aëration. }\end{array}$ \\
\hline $\begin{array}{l}\text { 3. Water of Class D; drawn in } \\
\text { sterile india-rubber - stopped } \\
\text { tubes. } \\
\text { 4. A second sample of same water } \\
\text { as } 3 \text {. } \\
\text { 5. Same water after aëration, in } \\
\text { syphon. }\end{array}$ & $\begin{array}{l}4 \text { hours after } \\
\text { drawing. } \\
4 \text { hours. } \\
4 \text { hours after } \\
\text { aëration. }\end{array}$ & $\begin{array}{l}7 \text { th. } \\
7 \text { th. } \\
5 \text { th. }\end{array}$ & $\begin{array}{r}1750 \\
1820 \\
649\end{array}$ & $\begin{array}{r}12 \\
0\end{array}$ & $\begin{array}{r}1760 \\
1832 \\
649\end{array}$ & $\begin{array}{l}\text { Before } \\
\text { aëration. } \\
\text { After } \\
\text { aëration. }\end{array}$ \\
\hline $\begin{array}{l}\text { 6. Water of Class D; drawn in } \\
\text { Pfuhl's tubes. } \\
\text { 7. A second sample of same water } \\
\text { as } 6 \text {. } \\
\text { 8. Same water after aëration, in } \\
\text { corked bottle. }\end{array}$ & $\begin{array}{l}4 \text { hours after } \\
\text { drawing. } \\
18 \text { hours in } \\
\text { ice. } \\
4 \text { hours after } \\
\text { aëration. }\end{array}$ & $\left\{\begin{array}{l}10 \text { th. } \\
9 \text { th. } \\
8 \text { th. }\end{array}\right.$ & $\begin{array}{r}905 \\
593 \\
1170\end{array}$ & $\begin{array}{r}0 \\
44\end{array}$ & $\begin{array}{r}905 \\
593 \\
1214\end{array}$ & $\begin{array}{l}\text { Before } \\
\text { aëration. } \\
\text { After } \\
\text { aëration. }\end{array}$ \\
\hline
\end{tabular}

The Table shows that the number of organisms present in the water used is considerable, that this number is slightly diminished or unaltered (taking into consideration the intervals between examination and numeration) in the case of the syphons, but that in the case of the corked bottle specimen there is a decided increase of bacteria in the aerrated water, together with the appearance of moulds which were originally absent. The bottles in this case were cleansed and rinsed out with ordinary unfiltered main water.

A glance at the results of chemical analysis shows that in nearly all cases the organic purity of these waters is very considerable. The 
chemical and bacteriological results do not show any close connection. This might be anticipated from the nature and sources of the biological contamination.

\section{The Action of $\mathrm{CO}_{2}$ on the Organisms Found in Mineral Waters.}

The results of the analysis of waters made between 2 and 7 days after aëration show no very marked differences from the results obtained with 24 -hours-old waters; the organisms were similar in kind and the numbers present not much less. Towards the end of the week, however, there seems to be a diminution in the rate of growth which rendered it possible to keep the plates longer.

With waters kept for 3 weeks and longer, however, the case is very different. There is a quite unmistakable diminution in the total number of bacteria present, as shown in Table $\mathrm{D}$. The proportional number of moulds also generally increases, though there are great individual differences in samples. The number of liquefying organisms, both actual and relative, becomes less, and, as a result, the plates can be kept and counted between the eighth and tenth days. Besides the diminution in number there is also a very decided change in the organisms, which renders the rate of development of the colonies much more slow. A culture of one of these old waters frequently shows no colonies for the first three days, a few on the fourth, and then an increase on the fifth or sixth day. In old kept waters I have rarely found more than a few moulds, an occasional colony of B. fluorescensliquefaciens, and a variable and sometimes large number of colonies of B. luteus. This latter seems to be one of the most resistant of organisms to the action of $\mathrm{CO}_{2}$.

This injurious action of $\mathrm{CO}_{2}$ on the organisms contained in water has been pointed out by Leone and Sohnke. The latter insisted on the comparative freedom from organisms of waters kept 1 to 9 months, and found three bottles examined when 3 to 4 years old to be absolutely sterile. Hochstetter came to the conclusion, on the contrary, that this diminution of micro-organisms in aërated water did not occur, and suggested that the results of Leone and Sohnke are due to their having destroyed the culture plates too soon, in ignorance of the retardation in development, due to the action of the $\mathrm{CO}_{2}$. This explanation will not apply to my results, which point strongly to an actual reduction in the number of microbes present. Hochstetter's results were obtained by examination, at successive dates, of different samples made (presumably?) from the same bulk of water. The great opportunities afforded in manufacture for variations in the biological purity of individual samples have already been pointed out, and it seems probable that Hochstetter's conclusions are due to these variations, the individual differences being more than sufficient to mask the progressive decrease. Thus in a distilled aërated water in corked bottles, examined when 
freshly made, the organisms varied from 73 to 2400 , and in a similar water kept 161 days the variations were between 770 and 66,000 .

The following Table, $\mathbf{E}$, shows the results of an examination of the same sample at different intervals. In the case of the bottled waters the samples were drawn by means of sterilised screw taps inserted through the corks. The results show a decided diminution of organisms under the prolonged action of $\mathrm{CO}_{2}$.

\section{TABLe E.}

Showing Result of the Examination of the same Samples at Different Intervals after Aëration.

\begin{tabular}{|c|c|c|c|c|c|}
\hline \multirow{2}{*}{ Origin of Water. } & \multirow{2}{*}{$\begin{array}{l}\text { Day on which } \\
\text { Colonies were } \\
\text { Counted. }\end{array}$} & \multicolumn{3}{|c|}{ Number of Organisms per c.c. } & \\
\hline & & Moulds. & Bacteria. & Total. & \\
\hline 1. Water of Class $B$; in & 6 th. & 2874 & 45 & 2919 & 4 hours after \\
\hline 2. Same sample. & 6th. & 374 & ... & 374 & $\begin{array}{l}7 \text { days after aëra- } \\
\text { tion. }\end{array}$ \\
\hline 3. Same sample. & 9th. & 410 & $\cdots$ & 410 & $\begin{array}{l}15 \text { days after } \\
\text { aëration. }\end{array}$ \\
\hline $\begin{array}{l}\text { 4. Water of Class } D \text {; in } \\
\text { syphon. }\end{array}$ & & 649 & $\ldots$ & 649 & $4 \underset{\text { hours after }}{\text { aëration. }}$ \\
\hline 5. Same sample. & 10th. & 259 & ... & 259 & $\begin{array}{l}35 \text { days after } \\
\text { aëration. }\end{array}$ \\
\hline $\begin{array}{l}\text { 6. Water, Class D; in corked } \\
\text { bottle. }\end{array}$ & Sth. & 1170 & 44 & 1214 & 18 hours after \\
\hline 7. Same sample. & 6 th. & 12 & 356 & 368 & 26 days after \\
\hline $\begin{array}{l}\text { 8. Water from same bulk as } \\
6 \text {, but not same sample. }\end{array}$ & 8th. & 59 & 22 & 81 & $\begin{array}{l}26 \text { days after } \\
\text { aèration. }\end{array}$ \\
\hline
\end{tabular}

It must always be borne in mind that the apparent diminution will depend on the variety of organisms present. Bacteria differ remarkably in their resistance to the action of $\mathrm{CO}_{2}$. In a water containing chiefly one of the resistant forms the diminution would be ill-marked. The water containing the greatest variety of organisms would probably show the greatest change. Two of these exceptional waters were met with in the course of this investigation. In one, an artesian-well water (soda) in syphon, the organisms were found to have increased rather than diminished, and the $B$. fluorescens liquefaciens was present in considerable numbers. The second was a charcoal-filtered ordinary tap water, which after five months contained about 2000 organisms per c.c. (Table C, No. $30)$. The bacteria consisted of three varieties - (1) a motile, roundended, thick bacillus, forming spores in cells of altered shape, and growing as a non-liquefactive thick opaque white colony spreading with irregular festooned edges on the surface of the gelatine; (2) a very small fine bacillus, like the $\mathcal{B}$. murisepticus, forming circular white moist 
non-liquefactive colonies ; and (3) an organism very similar, but forming yellow non-liquefactive growths. The last was present in the greatest numbers, and No. 1 was most seanty.

The observations on these waters were repeated several times, but identical results were obtained and the differences could not be due to experimental errors.

The diminution in numbers which appears to occur is due to the action of the $\mathrm{CO}_{2}$. Leone has shown that it is not due to the displacement of the oxygen present, as removal of this gas by hydrogen or the air-pump is not so injurious as its removal by $\mathrm{CO}_{2}$. It is also not due to the normal dying out of microbes, such as was noted by Meade Bolton in ordinary water, under the influence of time. This is shown by an examination of the aërated water, drawn and kept under sterile conditions after the carbonic acid has been allowed to escape. Such examination shows that after the loss of $\mathrm{CO}_{2}$ there is a rapid multiplication of organisms.

TABLE F.

Effect of Keeping Water after Loss of $\mathrm{CO}_{2}$.

\begin{tabular}{|c|c|c|c|c|c|}
\hline \multicolumn{3}{|c|}{ Before lass of $\mathrm{CO}_{2}$} & \multicolumn{3}{|c|}{ After loss of $\mathrm{CO}_{2}$. } \\
\hline Source of Water. & $\begin{array}{l}\text { Date of } \\
\text { Counting } \\
\text { Colonies. }\end{array}$ & $\begin{array}{l}\text { Organisms } \\
\text { per c.c. }\end{array}$ & $\begin{array}{l}\text { No. of Days } \\
\text { Water kept } \\
\text { after } \\
\text { loss of } \mathrm{CO}_{2 .}\end{array}$ & $\begin{array}{l}\text { Date of } \\
\text { Counting } \\
\text { Colonies. }\end{array}$ & Number of Organisms. \\
\hline 1. Water, Class B ; 4 & 6th day. & 2919 & $\cdots$ & $\cdots$ & $\cdots$ \\
\hline $\begin{array}{l}\text { 2. Same water, } 7 \text { days } \\
\text { aëration. }\end{array}$ & 6 th do. & 374 & 7 & 1st day. & $\begin{array}{l}\text { Colonies innumerable } \\
\text { in } 33 \text { c.c. }\end{array}$ \\
\hline $\begin{array}{l}\text { 3. Water, Class B ; } \\
\text { soda, } 24 \text { hrs. after } \\
\text { aëration. }\end{array}$ & 3rd day. & 645 & 28 & 1st day. & $\begin{array}{l}\text { Colonies innumerable } \\
\text { in } 22 \text { c.c. }\end{array}$ \\
\hline $\begin{array}{l}\text { 4. Water, Class A; } \\
\text { soda, } 4 \text { days after } \\
\text { aëration. }\end{array}$ & 2nd day. & 2615 & 36 & 1st day. & $\begin{array}{l}\text { Colonies iunumerable } \\
\text { in } 14 \text { c.c. }\end{array}$ \\
\hline $\begin{array}{l}\text { 5. Water, Class A; } \\
\text { sods, 20 days after } \\
\text { aeration. }\end{array}$ & 9th dey. & 34 & 28 & 1st day. & Innumerable in $5 \mathrm{c} . \mathrm{c}$. \\
\hline
\end{tabular}

\section{The Vitality of Pathogenic Organisms in AËrated Waters.}

The present investigation had for its end a practical object, viz. to determine what safeguards the use of aërated waters offered against infectious-water-carried diseases. The organisms selected for experiment were B. typhosus, Spirillum cholera (Koch), Spirillum cholerce nostras (Finkler and Prior), B. coli communis, Staphylococeus pyogenes aureus, and 
B. Alworescens liquefaciens. The first three were chosen as being the specific organisms of diseases admittedly spread by contaminated water; the $B$. coli communis because of the close relation which this organism bears to the B. typhosus, whether considered as a variety of the latter according to the Lyons school, or as aiding the growth and generalisation of B.typhosus in the infected body, as shown by Sanarelli and Chantemesse and Widal. The Staphylococcus pyogenes aureus was selected as typical of the group of micrococei, and as presenting the experimental advantage of being easily recognised, while the $B$. fuorescens (isolated from a sample of water) served to furnish a basis of comparison between pathogenic and the normally occurring non-pathogenic water organisms. The injurious action of $\mathrm{CO}_{2}$ on various organisms has beeu noted by many observers, but their experiments have usually reference to the action of gaseous $\mathrm{CO}_{2}$ on organisms in pure culture, suspended in fluid or disseminated throughout solid culture media. Buchner pointed out that the Spirillum choleres, exposed to an atmosphere of $\mathrm{CO}_{2}$, showed no signs of growth even in good culture media, while Emmerich's bacillus and the B.typhosus would still grow. C. Fränkel has very fully examined the action of gaseous $\mathrm{CO}_{2}$ on organisms diffused through thin layers of culture media, from which oxygen had been thoroughly removed. He found that the growth of the Spirillum cholerce and of the Finkler's spirillum was stopped absolutely, and that though the organisms were not all killed, yet their number was diminished and the rate of development slowed. The same observations were made as to a B. Aluorescens isolated from water. Staphylococcus pyogenes aureus grew slowly at $37^{\circ} \mathrm{C}$. (not at the ordinary temperature), and was injured by its exposure to the gas. B. typhosus, on the contrary, grew as in air. Fränkel showed that the organisms were not attenuated if not killed. Frankland made similar observations on the spirilla of cholera and cholera nostras, but found that an exposure of eight days to $\mathrm{CO}_{2}$ prevented subsequent development in air. Leone, Sohnke, and Reinl have examined the action of $\mathrm{CO}_{2}$ on organisms in water, but the most complete examination of the duration of vitality of pathogenic germs in ärated waters, under ordinary conditions, is by Hochstetter. He inoculated a number of corked aërated water bottles with suspensions of various germs in water, by means of a specially constructed syringe, and examined the bottles at different intervals. His results accord very closely with those obtained in my experiments.

Scala and Sanfelice examined the action of that amount of $\mathrm{CO}_{2}$ which normally occurs dissolved in water, at $15^{\circ} \mathrm{C}$. and atmospheric pressure, on various pathogenic organisms (Spirillum cholerce, $B$. anthracis, Staphylococcus aureus and albus, B. typhosus, and the bacillus of rabbit septicæmia), and concluded that it was without effect. If the amount of $\mathrm{CO}_{2}$ was increased, as by passing a stream of the gas through the water, then a harmful effect was exerted on Spirillum clolerce and $B$. anthracis. Apparently the action of the gas under 
pressure $^{x}$ was examined on $B$. subtilis and Proteus vulgaris only, with the result that the gas proved harmful to the vitality of $B$. subtilis, but left Proteus unaffected. The spores of $B$. anthracis and $B$. subtilis did not develop if exposed to a constant stream of $\mathrm{CO}_{z}$.

My own experiments were made to determine, if possible, the duration of the vitality of the organisms-

1. In simple unsterilised aërated water.

2. In sterilised water which had been made alkaline, and was subsequently aërated. For this purpose a soda-water made from artesian-well water, having an alkalinity equal to $0636\left(\mathrm{Na}_{2} \mathrm{CO}_{3}\right)$ per 100 c.c., was used.

The attempt was also made to gauge the pressure of the $\mathrm{CO}_{2}$, and by experimenting at different pressures to determine the effect of the pressure factor on the duration of vitality. A number of small sodawater bottles, containing about 150 c.c., were fitted with india-rubber corks, through which passed a short glass or metal tube, terminating just witbin the bottles. To the outer ends of the tubes was attached strong india-rubber tubing, wound round with linen for support, and securely wired on. By this tubing the bottle could be attached to a metal cross piece with four arms. To one arm the bottle was attached, the second passed to the source of aërated water, the third communicated with a pressure gauge, and the fourth was fitted with an india-rubber tube and serew pinch cork, and was used to blow off the air contained in the apparatus. The air was swept out by a stream of $\mathrm{CO}_{2}$, and in all cases the pressure was allowed to fall 5 or 10 lbs., two or more times, so that the air was thoroughly removed. The bottles plugged with cotton wool were sterilised by heating for one hour at $100^{\circ} \mathrm{C}$. The corks and attached tubes, inserted in test tubes, were, together with the cross piece and its connection, sterilised in the autoclave, the open ends of the tubes being plugged with wool. The bottles were infected with the specific germ, the wool-plugs of the bottles replaced by the sterilised corks, which were then wired in, and the bottles attached and wired on to the arm of the cross piece intended for them. Aërated water was then driven into the bottles, avoiding splashing as much as possible; the air driven out as described above, and then more water driven in, until the bottle was nearly full and the desired pressure reached. The screw clamp was then screwed down, the charged bottle detached, and a sterilised nozzle or tap inserted into the tube attached to the bottle. To examine the charged water, the bottle was inverted, the clamp unscrewed so as to allow the water to slowly drop from the nozzle, and after some drops had escaped two tubes of suitable nutrient medium were inoculated with about six drops each. Each examination employed about eighteen drops-six wasted, and six used in each of two tubes. The loss of pressure was therefore slight. The taps and nozzle were heated before each examination.

1 An abstract of this paper in the Centralbl. f. Bakteriologie was alone consulted, as the original paper was not available. 
In the experiments with soda-water the apparatus was modified. The bottles were fitted with corks bored with two holes; through one of these passed a long tube reaching to the bottom of the bottle, and through the other was passed a short tube with a tap. The bottles were sterilised as in the first case, filled with sterile soda-water through the long tube, and infected throngh the short one. The bottle was then attached as before to the arm of the eross piece, and $\mathrm{CO}_{2}$ passed in. The gas traversed a plug of sterile wool inserted in the tube leading to the gas supply. Air was drawn out by allowing the $\mathrm{CO}$, to escape from the tap. In some of these experiments $20 \mathrm{lbs}$. pressure was used instead of 15 , because it was found that the pressure dropped owing to the slowly progressive solution of the gas in the alkaline water.

The material used for inoculation was usually a young culture of the organism on nutrient agar, removed by a sterile wire and suspended in sterile distilled or sterile soda-water. The suspensions were rendered uniformly turbid, and about 15 to 2 e.c. were employed for each inoculation. Agar cultures were employed, in order that as little nutrient material as possible should be added to the water. The vitality of the organisms in the non-aërated waters used for infection of the bottles was also tested at intervals. This testing was done as a control on the aërated waters, but the conditions were not identical. The dilution was less, and the proportional amount of added nutrient medium, or organic matter derived from the organisms themselves, greater in these nonaërated than it was in the aierated waters; they are, however, comparable among themselves.

The pressures employed were one and two atmospheres. Ordinary bottled aërated water is at a pressure of $30-40 \mathrm{lbs}$. It was considered that 30 lbs. represented nearly enough the conditions of the commercial waters, without making the experiments unduly risky. The difference between one and two atmospheres should show the action of the pressure factor while solving the practical question as to whether the lowering of pressure in half-empty syphons would permit of a multiplication or a prolonged resistance of these pathogenic germs.

The results of the experiments are to be found in Tables I.-VI. :-

TABLE I.-B. Fluorescens Liquefaciens.

\begin{tabular}{|c|c|c|c|c|c|c|c|}
\hline \multirow[t]{2}{*}{$\begin{array}{l}\text { Age and Nature of } \\
\text { Culture used. }\end{array}$} & \multirow[t]{2}{*}{ Water used. } & \multirow[t]{2}{*}{$\begin{array}{l}\text { Pounds } \\
\text { Pressure } \\
\text { per } \\
\text { sq. inch. }\end{array}$} & \multirow[t]{2}{*}{$\begin{array}{l}\text { Hours or Days } \\
\text { after Inoculation } \\
\text { when Water was } \\
\text { Examined. }\end{array}$} & \multicolumn{2}{|c|}{$\begin{array}{l}\text { Organism found } \\
\text { to be still } \\
\text { Alive. }\end{array}$} & \multicolumn{2}{|c|}{$\begin{array}{l}\text { First Experi- } \\
\text { ment in which } \\
\text { the Organism } \\
\text { was found to } \\
\text { be Dead. }\end{array}$} \\
\hline & & & & Hours. & Days. & Hours. & Days. \\
\hline $\begin{array}{l}\text { 1. Culture on gela- } \\
\text { time at } 22^{\circ} \mathrm{C} ., 4 \\
\text { days old; or- } \\
\text { ganisms isolated } \\
\text { from water. }\end{array}$ & $\begin{array}{l}\text { Simple aërated, } \\
\text { non-sterilised. }\end{array}$ & 30 & $\begin{array}{l}\text { Detys } 2,15,9,11,13 \text {, } \\
16 .\end{array}$ & $\cdots$ & 16 & • & .. \\
\hline 2. & " & 30 & $\begin{array}{l}\text { Days } 2,6,9,11,13 \text {, } \\
\text { 16.? }\end{array}$ & $\cdots$ & $16 ?$ & $\cdots$ & $\ldots$ \\
\hline
\end{tabular}


TABLE II.-B. Coli Communis.

\begin{tabular}{|c|c|c|c|c|c|c|c|}
\hline \multirow[t]{2}{*}{$\begin{array}{l}\text { Age and Nature of } \\
\text { Culture used. }\end{array}$} & \multirow[t]{2}{*}{ Water used. } & \multirow[t]{2}{*}{$\begin{array}{l}\text { Pounds } \\
\text { Pressure } \\
\text { per } \\
\text { sq. inch. }\end{array}$} & \multirow[t]{2}{*}{$\begin{array}{l}\text { Hours or Days } \\
\text { after Inoculation } \\
\text { when Water was } \\
\text { Examined. }\end{array}$} & \multicolumn{2}{|c|}{$\begin{array}{l}\text { Organism found } \\
\text { to be still } \\
\text { Alive. }\end{array}$} & \multicolumn{2}{|c|}{$\begin{array}{c}\text { First Experi- } \\
\text { ment in which } \\
\text { the Organism } \\
\text { was found to } \\
\text { be Dead. }\end{array}$} \\
\hline & & & & Hours. & Days. & Hours. & Days. \\
\hline $\begin{array}{l}\text { 1. Agar culture at } \\
97^{\circ} \mathrm{C} \text {., 3 days old, } \\
\text { isolated from } \\
\text { case of diarrhoa. } \\
\text { 2. Similar enlture, }\end{array}$ & $\begin{array}{l}\text { Simple aërated, } \\
\text { non-sterile. }\end{array}$ & 15 & Days $2,4,6,8,9$. & .. & 6 & .. & 8 \\
\hline $\begin{array}{l}\text { 3. Salays old. } \\
\text { No. } 1 \text {. } \\
\text { 4. Same culture as } \\
\text { No. } 2 \text {. }\end{array}$ & $\begin{array}{c}\text { Sterile distilled, } \\
\text { non-aërated. } \\
\text { " }\end{array}$ & 0 & $\begin{array}{l}\text { Alive } 50 \text { days after } \\
\text { inoculation. } \\
\text { Alive 50 days after } \\
\text { inoculation. }\end{array}$ & $\begin{array}{l}. \cdot \\
. .\end{array}$ & $\begin{array}{l}. \\
.\end{array}$ & .. & .. \\
\hline
\end{tabular}

Table III.-Staphylococcus Pyogenes Aureus.

\begin{tabular}{|c|c|c|c|c|c|c|c|}
\hline \multirow[t]{2}{*}{$\begin{array}{l}\text { Age and Nature of } \\
\text { Culture used. }\end{array}$} & \multirow[t]{2}{*}{ Water used. } & \multirow[t]{2}{*}{$\begin{array}{l}\text { Pounds } \\
\text { Pressure } \\
\text { per } \\
\text { sq. inch. }\end{array}$} & \multirow[t]{2}{*}{$\begin{array}{l}\text { Hours or Days } \\
\text { after Inoculation } \\
\text { when Water was } \\
\text { Examined. }\end{array}$} & \multicolumn{2}{|c|}{$\begin{array}{l}\text { Organism found } \\
\text { to be still } \\
\text { Allve. }\end{array}$} & \multicolumn{2}{|c|}{$\begin{array}{l}\text { First Experi- } \\
\text { ment in which } \\
\text { the Organism } \\
\text { was found to } \\
\text { be Dead. }\end{array}$} \\
\hline & & & & Hours. & Days. & Hours. & Days. \\
\hline $\begin{array}{l}\text { 1. Agar culture at } \\
3^{7} \text { C., } 18 \text { hours } \\
\text { old. }\end{array}$ & $\begin{array}{l}\text { Simple aërated, } \\
\text { non-sterile. }\end{array}$ & 30 & Days 2, 6 . & .. & 2 & .. & 6 \\
\hline $\begin{array}{l}\text { 2. Agar enlture at } \\
37^{\circ} \mathrm{C} ., 18 \text { hours } \\
\text { old. } \\
\text { 3. " }\end{array}$ & $\left.\begin{array}{c}\text { Simpleaërated } \\
\text { non-sterile. } \\
"\end{array}\right\}$ & $\begin{array}{l}\text { Saturated } \\
\text { at ordin- } \\
\text { ary pres- } \\
\text { sure. }\end{array}$ & $\left\{\begin{array}{l}\text { Days } 1,2,3,5,6 . \\
\text { Days } 1,2,3,5,6 .\end{array}\right.$ & .. & 3 & .. & 5 \\
\hline $\begin{array}{l}\text { 4. Agar culture, } 37^{\circ} \\
\text { C., } 48 \text { hrs. old. } \\
\text { 5. }\end{array}$ & $\begin{array}{c}\text { Sterile soda. } \\
\text { water. } \\
\text { " }\end{array}$ & $\begin{array}{c}20 \\
\text { Not } \\
\text { aérated. }\end{array}$ & $\begin{array}{l}\text { Days } 3,4,5,7 . \\
\text { Days } 5,7,8,9,11 \text {, } \\
\text { I2. }\end{array}$ & $\begin{array}{l}. . \\
. .\end{array}$ & $\begin{array}{r}4 \\
11\end{array}$ & $\begin{array}{l}. . \\
. .\end{array}$ & $\begin{array}{r}5 \\
12\end{array}$ \\
\hline
\end{tabular}

Table IV.-B. Typhosus.

\begin{tabular}{|c|c|c|c|c|c|c|c|}
\hline \multirow[t]{2}{*}{$\begin{array}{l}\text { Age and Nature of } \\
\text { Culture used. }\end{array}$} & \multirow[t]{2}{*}{ Water used. } & \multirow{2}{*}{$\begin{array}{l}\text { Pounds } \\
\text { Pressure } \\
\text { per } \\
\text { sq. inch. }\end{array}$} & \multirow{2}{*}{$\begin{array}{l}\text { Hours or Days } \\
\text { after Innculation } \\
\text { when Water was } \\
\text { Examined. }\end{array}$} & \multicolumn{2}{|c|}{$\begin{array}{l}\text { Organism found } \\
\text { to be still } \\
\text { Alive. }\end{array}$} & \multicolumn{2}{|c|}{$\begin{array}{c}\text { First Experi- } \\
\text { ment in which } \\
\text { the Organisin } \\
\text { was found to } \\
\text { be Dead. }\end{array}$} \\
\hline & & & & Hours. & Days. & Hours. & Days. \\
\hline $\begin{array}{l}\text { 1. Culture on agar, } \\
37^{\circ} \mathrm{C} ., 24 \text { hours } \\
\text { old. } \\
2 . \quad \text { is }\end{array}$ & $\begin{array}{c}\text { Simple aërated, } \\
\text { non-sterile. } \\
*\end{array}$ & $\begin{array}{l}30 \\
30\end{array}$ & $\begin{array}{l}\text { Days } 2,6,9,11 . ? \\
\text { Days 2, 6, 9, } 11 \text {, } \\
13,16 .\end{array}$ & .. & $11 ?$ & $\therefore$ & 13 \\
\hline $\begin{array}{l}\text { 3. Culture on agar, } \\
3^{\circ} \mathrm{C} ., 48 \text { hours } \\
\text { old. } \\
\text { 4. } \\
5 .\end{array}$ & $\begin{array}{l}\text { Simple aërated, } \\
\text { non-sterile. } \\
\text { Sterile distilled. }\end{array}$ & $\begin{array}{c}15 \\
30 \\
\text { Not } \\
\text { aêrated. }\end{array}$ & $\begin{array}{l}\text { Days 4, } 0 . \\
\text { Days 4, 6, } 7 . \\
\text { Alive 50 days after } \\
\text { inoculation. }\end{array}$ & $\because$. & $\begin{array}{c}6 \\
. .\end{array}$ & .. & $\begin{array}{l}6 \\
7 \\
7\end{array}$ \\
\hline $\begin{array}{l}\text { 6. Culture on agar, } \\
37^{\circ} \mathbf{C} ., 48 \text { hours } \\
\text { old. } \\
\text { 7. " } 8 .\end{array}$ & $\begin{array}{c}\text { Sterile soda. } \\
\text { water. } \\
n \\
" 1\end{array}$ & $\begin{array}{c}20 \\
\\
30 \\
\text { Non- } \\
\text { aërated. }\end{array}$ & $\begin{array}{l}\text { Days } 5 . \\
\text { Days 5. } \\
\text { Days 5, 7,8, } 9 .\end{array}$ & $\because$ & .. & $\ddot{. .}$ & $\begin{array}{l}5 \\
9\end{array}$ \\
\hline
\end{tabular}


TABLE V.-Spirillum Finkleri.

\begin{tabular}{|c|c|c|c|c|c|c|c|}
\hline \multirow[t]{2}{*}{$\begin{array}{l}\text { Age and Nature of } \\
\text { Culture used. }\end{array}$} & \multirow[t]{2}{*}{ Water used. } & \multirow[t]{2}{*}{$\begin{array}{l}\text { Pounds } \\
\text { Pressure } \\
\text { per } \\
\text { sq. inch. }\end{array}$} & \multirow[t]{2}{*}{$\begin{array}{l}\text { Hours or Days } \\
\text { after Inoculation } \\
\text { when Water was } \\
\text { Examined. }\end{array}$} & \multicolumn{2}{|c|}{$\begin{array}{l}\text { Organism found } \\
\text { to be still } \\
\text { Alive. }\end{array}$} & \multicolumn{2}{|c|}{$\begin{array}{c}\text { First Experi- } \\
\text { ment in which } \\
\text { the Organism } \\
\text { was found to } \\
\text { be Dead. }\end{array}$} \\
\hline & & & & Hours. & Days. & Hours. & Days. \\
\hline $\begin{array}{l}\text { 1. Agar culture, } 3 \pi^{\circ} \\
\text { C., } 48 \text { hrs. old. } \\
2 . \\
3 .\end{array}$ & $\begin{array}{c}\text { Simple aërated, } \\
\text { non-sterile. } \\
\text { "I } \\
\text { Distilled sterile. }\end{array}$ & \begin{tabular}{|c|}
15 \\
30 \\
Non- \\
aèrated.
\end{tabular} & $\begin{array}{l}\text { Hours } 2,3,4,5 . \\
\text { Hours } 1,2,3,4,5 \\
\text { Hours } 4,5,6 .\end{array}$ & .. & $\begin{array}{l}\cdots \\
\cdots \\
\cdots\end{array}$ & $\begin{array}{l}2 \\
1 \\
6\end{array}$ & $\begin{array}{l}\cdots \\
\cdots\end{array}$ \\
\hline $\begin{array}{l}\text { 4. Agar culture, } 37^{\circ} \\
\text { C., } 48 \text { hrs. old. } \\
\text { 5. } \\
6 .\end{array}$ & $\begin{array}{c}\text { Simple aërated, } \\
\text { non-sterile. } \\
\text { " } \\
\text { Distilled sterile. }\end{array}$ & \begin{tabular}{|c|}
15 \\
30 \\
Non- \\
aërated.
\end{tabular} & $\begin{array}{l}\text { Hours } \frac{1}{2}, 1,2 . \\
\text { Hours } \frac{1}{1}, 1,2 . \\
\text { Hours } 3,4,5 ; \text { days } \\
\quad 1,2 .\end{array}$ & $\begin{array}{r}\frac{1}{2} \\
\frac{1}{2} \\
.\end{array}$ & $\ddot{i}$ & $\begin{array}{l}1 \\
1 \\
\cdots\end{array}$ & $\because$ \\
\hline $\begin{array}{l}\text { 7. Agar culturc, } 37^{\circ} \\
\text { C., } 4 \text { days old. } \\
\text { 8. } \\
\text { 9. Agar culture, } 37^{\circ} \\
\text { C., } 48 \text { hrs. olr. } \\
\text { 10. }\end{array}$ & $\begin{array}{c}\text { Sterile soda. } \\
\text { water. } \\
\text { "1 }\end{array}$ & \begin{tabular}{|c|}
20 \\
Non- \\
aërated. \\
30 \\
Non- \\
aërated
\end{tabular} & $\begin{array}{c}\text { Hours } \frac{1}{4}, \frac{2}{2}, 55 \text { mins. } \\
\text { Hours } 4 \text {; days } 1,2 . \\
\text { Hours } \frac{1}{2}, \frac{5}{4}, 1,1 \frac{1}{4} . \\
\text { Hours } 4 \text {; days } 1 \text {, } \\
\quad 2,3,4,6 .\end{array}$ & $\begin{array}{c}55 \text { mins. } \\
4 \\
\ldots \\
\ldots\end{array}$ & $\begin{array}{l}\cdots \\
\cdots \\
4\end{array}$ & $\begin{array}{l}\cdots \\
\cdots \\
\frac{1}{2} \\
\cdots\end{array}$ & $\begin{array}{c}\cdots \\
1\end{array}$ \\
\hline $\begin{array}{l}\text { 11. Agar culture, } 3 \% \\
\text { C., } 48 \text { hrs. old. } \\
\text { 12. } \\
\text { 13. }\end{array}$ & $\begin{array}{c}\text { Sterile soda- } \\
\text { water. } \\
\text { " } \\
\text { " }\end{array}$ & \begin{tabular}{c|}
15 \\
30 \\
Non- \\
aërated.
\end{tabular} & $\begin{array}{l}\text { Hours } \frac{1}{4}, \frac{1}{2}, \frac{3}{4}, 1,1 \frac{1}{2}, \\
2,3 . \\
\text { Hours } \frac{1}{4}, \frac{2}{2}, \frac{3}{4}, 1, \\
1 \frac{1}{2}, 2,3 . \\
\text { Hours } 4 ; \text { days } 1,2, \\
3,5,6,7,8,9, \\
10,12 .\end{array}$ & $\begin{array}{l}\frac{3}{4} \\
1 \\
\cdots\end{array}$ & $\begin{array}{c}\cdots \\
\cdots \\
10\end{array}$ & $\begin{array}{l}1 \\
1 \frac{1}{2} \\
\cdots\end{array}$ & $\begin{array}{l}\cdots \\
\cdots \\
12\end{array}$ \\
\hline
\end{tabular}

\section{Table VI-_Spirillum Cholerce.}

\begin{tabular}{|c|c|c|c|c|c|c|c|}
\hline \multirow[t]{2}{*}{$\begin{array}{l}\text { Age and Nature of } \\
\text { Culture used. }\end{array}$} & \multirow[t]{2}{*}{ Water used. } & \multirow[t]{2}{*}{$\begin{array}{l}\text { Pounds } \\
\text { Pressure } \\
\text { per } \\
\text { sq. inch. }\end{array}$} & \multirow[t]{2}{*}{$\begin{array}{l}\text { Hours or Days } \\
\text { after Inoculation } \\
\text { when Water was } \\
\text { Examined. }\end{array}$} & \multicolumn{2}{|c|}{$\begin{array}{l}\text { Organism found } \\
\text { to be still } \\
\text { Alive. }\end{array}$} & \multicolumn{2}{|c|}{$\begin{array}{c}\text { First Experi- } \\
\text { ment in which } \\
\text { the Organism } \\
\text { was found to } \\
\text { be Dead. }\end{array}$} \\
\hline & & & & Hours. & Days. & Hours. & Days. \\
\hline $\begin{array}{l}\text { 1. Culture on Agar, } \\
37^{\circ} \mathrm{C} ., 45 \text { lirs. } \\
\text { old. " } \\
\text { 2. } \\
\text { 3. " " }\end{array}$ & $\begin{array}{c}\text { Simple aërated, } \\
\text { non-sterile. } \\
\text { sterile "listilled. }\end{array}$ & $\begin{array}{c}15 \\
\\
30 \\
\text { Non- } \\
\text { aërated. }\end{array}$ & $\begin{array}{l}\text { Hours } \frac{1}{2}, 1,2,3,4 . \\
\text { Hours } \frac{1}{3,1}, 2,3,4 . \\
\text { Hours } 1 \frac{1}{4}, 3,4, \\
\quad \text { 5; days } 1 .\end{array}$ & $5^{\frac{1}{2}}$ & $\begin{array}{l}\cdots \\
\cdots\end{array}$ & $\begin{array}{l}\frac{1}{*} \\
1 \\
\cdots\end{array}$ & $\ddot{i}$ \\
\hline $\begin{array}{l}\text { 4. Culture on Agar, } \\
37^{\circ} \text { C., } 24 \text { hrs. } \\
\text { old. " } \\
\text { 5. " } \\
\text { 6. " }\end{array}$ & $\begin{array}{c}\text { Sterile soda- } \\
\text { water. } \\
\text { "" }\end{array}$ & $\begin{array}{c}15 \\
30 \\
\text { Non- } \\
\text { aërated. }\end{array}$ & $\begin{array}{l}\text { Hours } \frac{1}{\frac{1}{3}}, 1,1 \frac{1}{2}, 2 \frac{1}{2}, \\
\quad 3 \frac{1}{2}, 4 \frac{1}{2}, 5,6 \frac{1}{2}- \\
\text { Hours } \frac{1}{2}, 1,2,3,4, \\
5,6,7 . \\
\text { Hours } 2,8,4,5,6, \\
7,8,9 ; \text { days } 1 .\end{array}$ & $\begin{array}{l}\cdots \\
9\end{array}$ & .. & $1 \frac{1}{3}$ & $\begin{array}{l}\cdots \\
1\end{array}$ \\
\hline $\begin{array}{l}\text { 7. Agar culture, }{ }^{2} 87^{\circ} \\
\text { C., } 48 \text { hrs. old. } \\
\text { 8. } \\
\text { 9. " }\end{array}$ & $\begin{array}{cc}\text { Sterile } & \text { soda- } \\
\text { water. } & \\
\text { " } & \\
\text { " } & \end{array}$ & $\begin{array}{c}15 \\
30 \\
\text { Non- } \\
\text { aërated. }\end{array}$ & $\begin{array}{l}\text { Hours } \frac{1}{4}, \frac{1}{2}, \frac{3}{4}, 1,1 \frac{1}{2}, \\
2,3 \frac{1}{4} \\
\text { Hours } \frac{1}{4}, \frac{1}{2}, \frac{3}{4}, 1,1 \frac{1}{2}, \\
2,3 \frac{1}{2} . \\
\text { Hours } 5 ; \text { days } 1,2, \\
3,5,6,7,8,9,10 .\end{array}$ & $\begin{array}{l}\frac{1}{2} \\
\frac{1}{4}\end{array}$ & $\begin{array}{l}\cdots \\
\cdots \\
9\end{array}$ & $\begin{array}{l}\frac{5}{4} \\
\frac{1}{3}\end{array}$ & $\begin{array}{l}\ddot{ } \\
\cdots \\
10\end{array}$ \\
\hline
\end{tabular}

1 This culture was made from a gelatine culture at ternperature $18^{\circ} \mathrm{C}$. due to this. 
The length of time during which the various organisms retain their vitality varied considerably. They could, however, be divided into wellmarked groups, though in these groups individual differences appeared. That the results of experiment should vary, even considerably, was to have been expected from the great discrepancies in the length of vitality. noted by previous investigators.

As was to be expected, the ordinary water organism, B. fluorescens liquefaciens, showed the greatest resistance. It was still living after sixteen days' exposure, when the experiments ceased ; it was, however, met with in commercial waters living and uninjured after more than five weeks' exposure.

Of the pathogenic germs, the $B$. typhosus and the B. coli communis form a group able to retain their vitality after at least seven days' exposure, and not certainly destroyed until the lapse of a fortnight, in ordinary unsterile aërated water. The longest period during which $B$. typhosus was found alive was eleven days, and the shortest period in which it was found to be killed was six days. The earliest period at which the $B$. coli communis died was eight days. It was alive up to the seventh day.

In sterile distilled water the vitality of both bacilli persisted more than two months.

The use of alkaline as opposed to ordinary water seems to shorten the period of resistance of these organisms, in both aërated and nonaïrated waters. B. typhosus dies before the fifth day in aërated alkaline water, and between the eighth and ninth in non-aërated soda-water. The organism is known to withstand large doses of acid, but seems atfected by the alkali.

The Staphylococcus pyogenes aureus holds an intermediate position between the previous group and one formed by the two varieties of spirilla. It appears to live in simple aërated water, and also in sodawater from two to four days, dying before the fifth day. In sterilised non-aërated soda-water it was alive after eleven days.

The organisms of the fourth group show a very much smaller resistance to the action of the aërated water. The longest period during which either spirillum was found alive was one hour, and this was in a sterilised alkaline water. In ordinary aërated water the vitality was not found to persist beyond half an hour. The apparent increase in resistance in the alkaline water was to be expected, knowing, as we do, the importance of a decidedly alkaline medium for their culture. The action of the sodium salt was more marked in a non-aërated water.

The action of the pressure factor, in the effect produced by the gas on micro-organisms, does not appear to be very important. The results obtained vary capriciously, and the variations are apparently due to indirect causes, differences in cultures or methods of experiments rather than to variation in pressure.

The Spirillum cholerce was the only one in which the increase of pressure 
seemed to cause diminished vitality with any constancy, though there are indications of the same relations in the case of Spirillum finkleri.

The conclusion at which I have arrived, from the recorded experiments, and also from a number in which the experimental pressure was not kept up owing to failure of apparatus, etc., is that the pressure is unimportant, and that organisms die as quickly in water, thoroughly saturated with the gas, as they do in water in which the gas is under pressure. This conclusion is not opposed to the results of Scala and Sanfelice, as the amount of gas present in what I describe as thoroughly saturated water was not less than that occurring in water through which a stream of $\mathrm{CO}_{2}$ is being passed, and indeed in most cases there was a residual pressure of $\frac{1}{2}$ to $1 \mathrm{lb}$. It does not appear, then, that the loss of $\mathrm{CO}_{2}$ in partially used syphons would lead to the multiplication of any of the pathogenic organisms experimented with, and the results of the analysis of syphons at different dates show that the diminution in number of the ordinary non-pathogenic organisms proceeds notwithstanding the partial loss of pressure.

The conclusions which may be drawn from the foregoing observations may be summarised thus :-

1. That artificial aërated waters contain a considerable number of unicro-organisms.

2. The number present in the finished waters gives no clue to the original purity of the source of supply, or to the efficacy of the methods of purification.

3. That there is a decided decrease in the number of micro-organisms present in the aërated waters when these are kept. The decrease is most noticeable after about three weeks. It is of general but not constant occurrence.

4. The decrease is due to the presence of carbon dioxide-loss of the gas being followed by increase in number of micro-organisms. The bacteria, therefore, are not in all cases killed, but have their development arrested.

5. Carbon dioxide in solution kills certain pathogenic germs. The period of resistance varies with the organism.

6. Pressure does not appear to be an important factor.

A bacteriological examination alone does not furnish complete data for answering the important question as to the safety of aerrated waters as beverages. Supplementing bacteriological with ordinary hygienic inquiry, it appears that the water employed for aüration is drawn from trustworthy sources, and is carefully stored so as to show no risk of serious contamination. The processes adopted for purification are also satisfactory guarantees against dangers existing in the source of supply, though, in many cases, the initial biological purity of the water undergoes impairment in the process of manufacture. The advantage of using a purification process, such as distilling or boiling, is that risk attending accidental contamination of the source is eliminated. As a rule the 
contamination during manufacture does not imply the possibility of the entrance of pathogenic germs, but there is certainly a risk, though it may be slight, in the use of improperly cleansed bottles.

Airation undoubtedly increases the safety of water. It offers i practically absolute safeguard against cholera, since the Spirillum cholerce and Spirillum Finkleri are both so rapidly killed, that the water could hardly be used before these germs were dead.

The safeguards against typhoid are by no means so complete. Hochstetter quotes the case of an epidemic of typhoid occurring at Mainz in 1884, which was traced to the use of contaminated aërated water. Aërated waters are often drunk within a few days of manufacture. Safety would hardly be absolute unless the waters were kept for a fortnight after aëration before being consumed.

It is assumed here that the safety of the water is coincident with the death of the pathogenic organisms. It is possible, however, that practical safety may be assured at an earlier date, owing to the temporary attenuation of the organisms by the carbonic acid gas. Permanent attenuation is apparently not produced by the action of $\mathrm{CO}_{2}$. This was shown by Hochstetter to be true in the case of the spores of B. anthracis and Aspergillus flavescens exposed for 56 to 154 days in aïrated water. Frïnkel showed that the virulence of $M$. tetragenus, $B$. anthracis, and the organisms of chicken cholera and mouse septicæmia, was also unchanged by exposure to an atmosphere of carbon dioxide. On the other hand, that temporary attenuation may probably occur is indicated by the retardation in the rate of development of the organisms, and by the occasional, almost complete, loss of the power of liquefying gelatine produced by the action of the gas. It is probable that similar modifications of the pathogenic properties of the microbes may occur, though experiments are wanting on this point. Since, however, it has been shown that the association of micro-organisms may revive the pathogenic power of even highly-attenuated organisms (as in the case of B. typhosus), it would seem wiser, at present, not to trust to this loss of virulence, more particularly as the death of the pathogenic germs occurs within such a comparatively short time.

An aërated water made from a good source, and kept for more than fourteen days, would then appear to offer complete safety from the usual water-carried diseases.

\section{APPENDIX.}

Since the remarks (p. 475) on the use of a spray of untreated mainwater for rinsing bottles were written, several manufacturers have modified their methods, and now use water which has been distilled or filtered through a Pasteur-Chamberland filter. In one case the artesianwell water used for aüration has always been employed to finally cleanse the bottles. To the methods used in purifying the original water must 
now be added filtration through Pasteur-Chamberland or Berkefeld filters. An analysis of bottled aërated water prepared from main-water passed through a Berkefeld filter showed the presence of a comparatively small number of micro-organisms; but, as specially sterilised bottles and corks had been used, the results cannot be compared with those given in the text; nor were the conditions those obtaining in commercial waters.

Though aërated water is often drunk, as stated, very shortly after manufacture, yet it is the endeavour of most makers to keep the water for a week or more before selling.

\section{REFERENCWS}

Buchner, . . . . . . Archiv f. Hygiene, 1885, Bd. iii., p. 410.

LEONe, . . . . . . . Do. do., 1886, Bd. iv., p. 175.

SoHnke, . . . . . . Zeitschr. $f$. Mineralwasser-fabrikation, 1886.

RIENL, . . . . . . . Wiener. med. Wochensch., 1888, Nos. 22 and 23.

HochsteтTEк, . . . .'Arbeiten. aus dem Kaiserlich. Gesund., 1887, Bil. ii., p. 1.

Frankland, . . . . . Zeitschr. f. Hygiene, 1889, Bd. vi., p. 13.

C. Frünkel, . . . . . Do. do., 1889, Bd. v., p. 332.

Meade Boliton, . . . . Do. do., 1886, p. 76.

Sayarelli, . . . . Annales de l'Institut Pasteur, 1892, tome vi., p. 71.

Chantemesse and Widal, do. do. $\quad 1892$, tome vi., p. 71 .

Scala and Sanfeuree, . Bull. d. $r$. Accad. medica di Roma, anno 16.

Centrallh. f. Bahteriologie, 1891, Bd. ix., p. 110. 